\title{
Employee Satisfaction in ITC Grand Chola Hotels
}

\author{
Magdalene Peter. S.Fabiyola Kavitha, Kieerti Reddy
}

\begin{abstract}
Thinking about this has been a startup commercial enterprise enterprise entering into second yr, it favored to test out ranges of pride earlier than coming up with new rules to take destiny direction of movements. $i$ was given the task to apprehend the numerous elements associated with employees pleasure in the employer.ITC hotels moreover favored to make out an external survey in indentifying the benefits other enterprise gives to its employees and take a look at the ones things along aspect the blessings supplied via the commercial enterprise organization. agency moreover wanted to recognize personnel know-how of business enterprise'sproject and imaginative and prescient assertion. organisation additionally preferred to check employees delight degrees with their crew leaders, with the manage and in the organization participants. The primary goal of this undertaking is to conduct a have a examine on employees courting control at area Host for the inn enterprise. The look at can be carried thru through getting the comments from the employees and examine the ones outcomes with the predicted outcomes. through reading and comparing the notion of the personnel of domain Host we're capable of get an powerful dating with the personnel. it's miles crucial that to hold a robust dating with personnel. this may assist area Host to establish an inexpensive proportion in the market region [1],[3],[5]
\end{abstract}

Keywords : ITC,Employee,employer

\section{INTRODUCTION}

Regardless of the fact that dedicated and dependable employees are the maximum influential detail to turning into an commercial enterprise enterprise of choice, it's far no wonder that businesses andorganizations face giant disturbing situations in growing energized and engaged workforces. but, there may be masses of research to show that improved worker dedication and receive as real with in management can undoubtedly effect the enterprise's backside line. In fact, the real capability of an organisation can first-class be realized even as the productiveness level of every person and corporations are fully aligned, devoted and energized to efficaciously accomplish the dreams of the employer As a give up end result, the goal of each corporation need to be to beautify the choice of personnel to stay inside the dating they have got with the enterprise. while

Revised Manuscript Received on July 22, 2019

Magdalene Peter, Department of MBA, Bharath Institute of Higher Education and Research, Tamilnadu, India. Email: magdalene.bsb@gmail.com

Dr.S.Fabiyola Kavitha, Department of MBA, Bharath Institute of Higher Education and Research, Tamilnadu, India. Email: fabiyolakavitha@gmail.com

Kieerti Reddy, Department of MBA, Bharath Institute of Higher Education and Research, Tamilnadu, India. Email: kieertreddymbagmail.com companies understand and manage worker loyalty - in place of retention specially - they might obtain benefits on both sides of the stableness sheet sales and prices.at the revenue facet of the stability sheet, dependable and devoted personnel are more likely to move "above and beyond" to meet personnel desires and are exceedingly recommended to art work to the quality of their capacity. on the price aspect, loyal employees stay longer, withstand aggressive method gives, do notactively look for different employment and suggest the corporation to others as a high-quality vicinity to paintings. those four behaviors truely impact the fee aspect of the steadiness sheet. In exceptional words, as opposed to focusing simplest on retention (that is, looking to keep personnel who have already decided to depart), businesses want to proactively understand the blessings of information, coping with and improving worker pleasure. The most a success agencies are those which can adapt their organizational conduct to the realities of the modern-day work surroundings in which achievement is based upon innovation, creativity and versatility. one of the key steps to records and enhancing employee pleasure is via way of acknowledging the importance of the following elements in building loyalty and pride[2 ],[ 4],[6]

\section{RESEARCH METHODOLOGY}

Studies method is one of the main elements of very research. This explains how the researcher conducts this assignment. The phrase research shows the mode or the manner of wearing out an give up. The modern global is full of clinical [8],[10], [12] improvements and seeks a systematic outlook to the whole lot. Any clinical method have to have a method or define to be followed to gain a selected intention. thru methodological, systematic technique, we can consider accuracy and easy reduce conclusion. there may be no area without technique. The method observed in this test is discussed under in short. [7],[9], [11] 


\section{Employee Statsfication in ITC Grand Chola Hotels}

\section{OBJECTIVES OF THE STUDY}

\section{A. Primary Objective}

To Study the Employees Relationship Management of Employers in Chennai

\section{B. Secondary Objective}

1. To compare the expectations of the Employees of Employers with the actual services delivered by the company.

2. To identify the Employees opinion on Employers resolution of complaints.

3. To determine the Employees' satisfaction on Employers services and their intention towards availing of Employers services in future.

Table 1 Showing the association of Employees with Employers International

\begin{tabular}{|l|l|l|}
\hline Years & Respondents & Percent \\
\hline$<1$ year & 18 & 18 \\
\hline $1-2$ years & 28 & 28 \\
\hline $2-3$ years & 36 & 36 \\
\hline$>3$ years & 18 & 18 \\
\hline Total & 100 & 100.0 \\
\hline
\end{tabular}

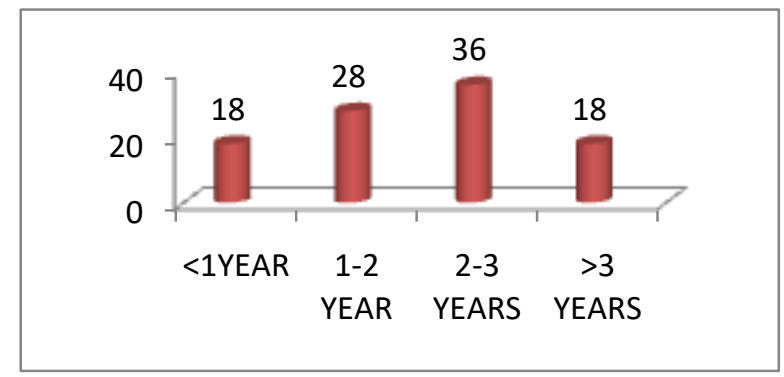

Fig:1 Showing the association of Employees with Employers International

\section{Inference}

The above chart indicates that $36 \%$ of personnel are availing offerings from Employersfor extra than 2 years to much less than three years, $28 \%$ are availing services forabout $1-2$ years, $18 \%$ are availing offerings from Employers forabout2-3 yearsand $18 \%$ are availing services from more than 3 years. hence, the provider lag has been there that needs to be advanced with employees of Employers. [14],[ 16], [18]

Table2:.Showing the evaluation and comparison of the services provided by Employers against the services provided by other companies

\begin{tabular}{|l|l|}
\hline Attributes related to service delivery & $\begin{array}{l}\text { Evaluation of Employees response by } \\
\text { comparing EMPLOYERS's service } \\
\text { delivery with other companies }\end{array}$ \\
\hline Personnel & 2.5 \\
\hline Timely communication & 2.3 \\
\hline Customized solution & 2.2 \\
\hline Post-delivery guidance & 1.89 \\
\hline Consistency in service quality & 1.89 \\
\hline Promptness & 1.84 \\
\hline Grievance Redressal & 1.84 \\
\hline Honoring deadliness & \\
\hline Price & \multicolumn{2}{|c|}{1.82} \\
\hline $\begin{array}{l}\text { Weights: 1- worse than EMPLOYERS, } \\
\text { EMPLOYERS }\end{array}$ & \\
\hline
\end{tabular}

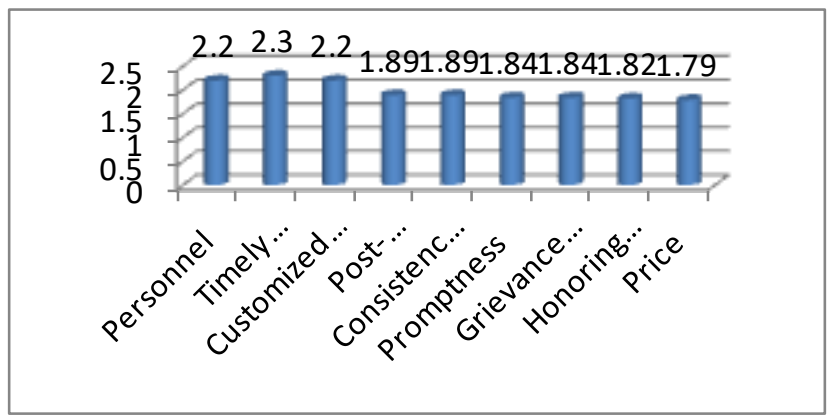

Fig:2 Showing the evaluation and comparison of the services provided by EMPLOYERS against the services provided by other companies

Inference:

The above graph suggests that employees, nicely timed conversation and customized solutions are the attributes in which one-of-a-kind businesses are higher than EMPLOYERS. positioned up shipping steerage, consistency in service great, promptness, grievance redressal, honoring deadliness and fee are the attributes in which EMPLOYERS is better than different businesses. [13], [15] , [17]

Table:3 .Showing the evaluation and comparison of the services provided by EMPLOYERS against the services provided by major competitors (Taj and Heritage)

\begin{tabular}{|l|l|}
\hline Attributes related to service delivery & $\begin{array}{l}\text { Evaluation of Employees response by } \\
\text { comparing EMPLOYERS's service delivery } \\
\text { with Taj \& Heritage }\end{array}$ \\
\hline Customized solutions & 2.3 \\
\hline Personnel & 2.22 \\
\hline Timely communication & 2.13 \\
\hline Honoring deadliness & 2.02 \\
\hline Consistency in service quality & 1.86 \\
\hline Promptness & 1.76 \\
\hline Post delivery guidance & 1.73 \\
\hline Price & 1.7 \\
\hline Grievance redressal & 1.7 \\
\hline $\begin{array}{l}\text { Weights: 1- worse than EMPLOYERS, 2- same as EMPLOYERS, 3- better than } \\
\text { EMPLOYERS }\end{array}$ & \\
& \\
& $\begin{array}{l}\text { Published By: } \\
\text { Blue Eyes Intelligence Engineering } \\
\text { \& Sciences Publication }\end{array}$
\end{tabular}




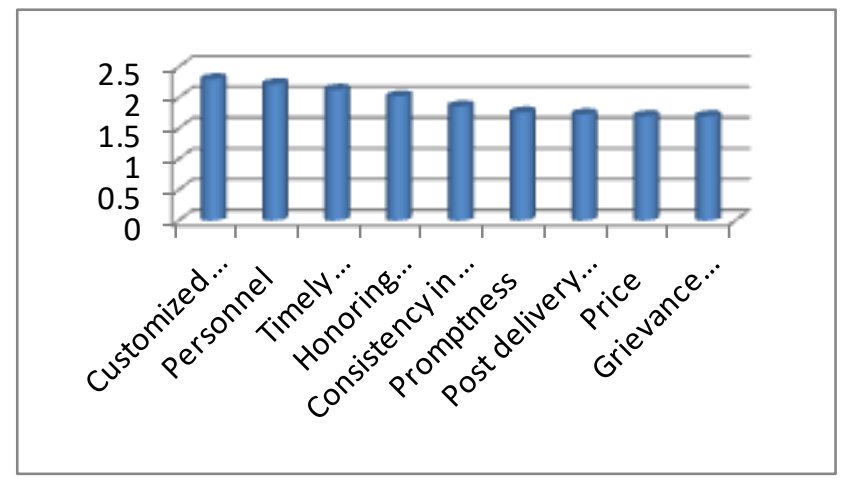

Fig:3 .Showing the evaluation and comparison of the services provided by EMPLOYERS against the services provided by major competitors (Taj \& Heritage)

\section{Inference:}

The above graph shows that customized solutions, personnel, timely communication, honoring deadliness are the attributes in which (Taj \& Heritage)are better than EMPLOYERS. Promptness, post delivery guidance, price, grievance redressal are the attributes in which EMPLOYERS is better than (Taj \& Heritage). [20],[ 22], [24]

Table :4 Showing the evaluation of the agreement to the statements given by the Employees which are related to EMPLOYERS
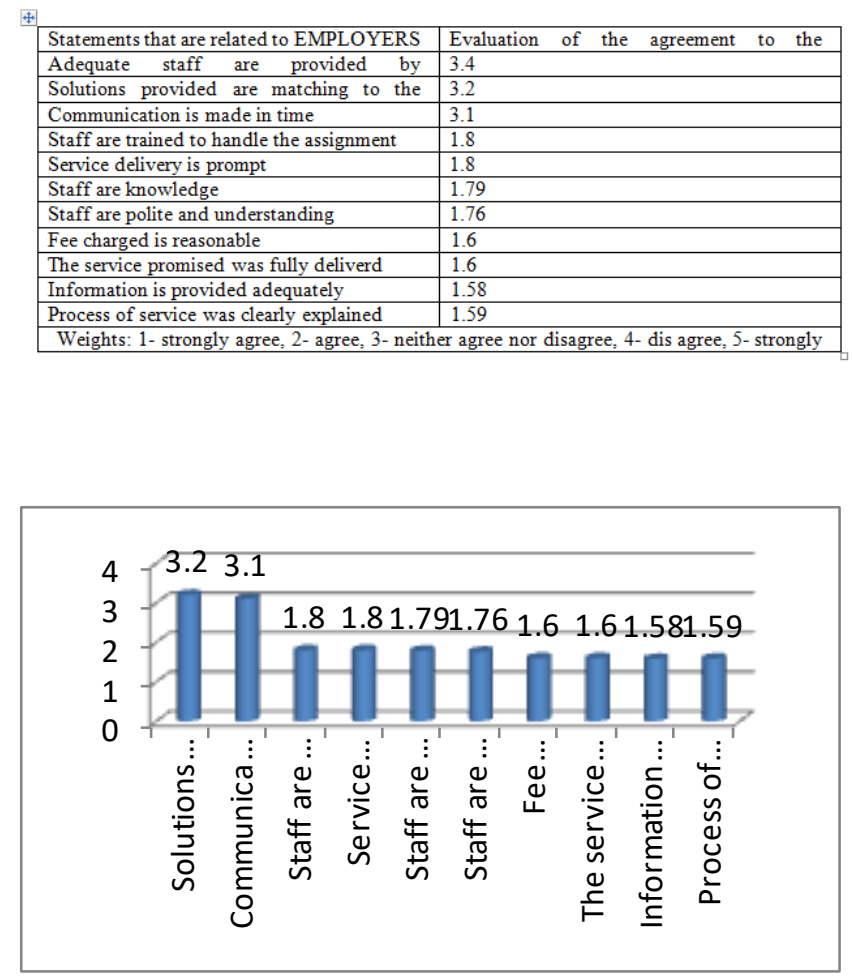

Fig:4 Showing the evaluation of the agreement to the statements given by the Employees which are related to EMPLOYER

\section{Inference:}

The above graph shows that adequate staff provided by the company, customized solutions provided by the company and timely communication are the statements where Employees disagree and rest of statements are agreed by the Employees. [19],[21],[23]

Table:5 Test of Homogeneity of Variances

\begin{tabular}{|l|l|l|l|}
\hline $\begin{array}{l}\text { Levene } \\
\text { Statistic }\end{array}$ & df1 & df2 & Sig. \\
\hline 7.615 & 1 & 98 & .007 \\
\hline
\end{tabular}

\section{ANOVA}

\begin{tabular}{|c|c|c|c|c|c|c|c|}
\hline & & & \begin{tabular}{|ll} 
Sum of \\
Squares
\end{tabular} & df & \begin{tabular}{|l|} 
Mean \\
Square
\end{tabular} & $\mathrm{F}$ & Sig. \\
\hline Between & \multicolumn{2}{|c|}{ (Combined) } & .118 & 1 & .118 & 2.506 & .117 \\
\hline \multirow[t]{2}{*}{ Groups } & Linear & Unweighted & .118 & 1 & .118 & 2.506 & .117 \\
\hline & Term & Weighted & .118 & 1 & .118 & 2.506 & .117 \\
\hline \multicolumn{3}{|c|}{ Within Groups } & 4.632 & 98 & .047 & & \\
\hline \multicolumn{3}{|l|}{ Total } & 4.750 & 99 & & & \\
\hline
\end{tabular}

\section{MEANS PLOT}

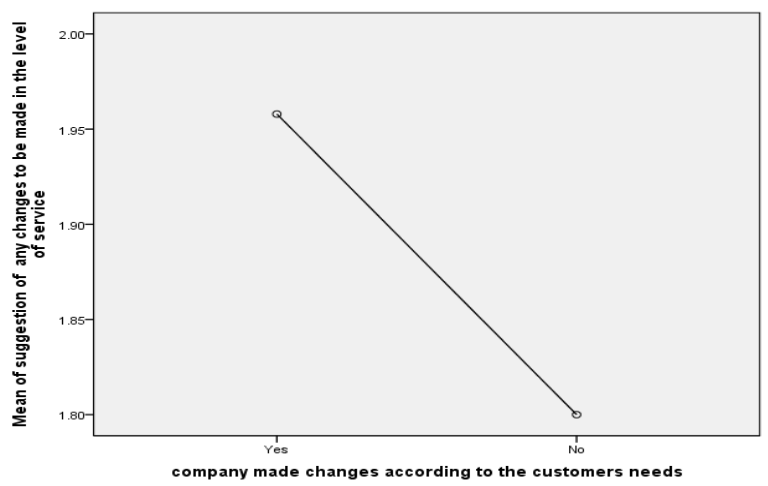

Fig:5

Tabulated value $=\mathbf{3 . 9 2}$

\section{Calculated value $=\mathbf{2 . 5 0 6}$}

INFERENCE:

The calculated value of $\mathrm{F}$ is less than the tabulated cost. as a result, we receive the null speculation and conclude that there's no importance distinction between the suggestions given by the personnel throughout the service time and the the organisation made changes in step with the employees want.

\section{RESULTS AND DISCUSSION}

After being a part of entire survey i.e. from training of questionnaire to theeducation of very last record, i used that permits you to understand the advantages from the survey done and moreover identified a number of the regions wherein 


\section{Employee Statsfication in ITC Grand Chola Hotels}

employees confirmeddissatisfaction, which may be as follows: [25],[27],[29]

1. Personnel have been thrilled to artwork with ITC inns. 2. People expressed their self warranty on top of things of ITC lodges three.

3. Most of the employees have been not clean about the undertaking \& imaginative and prescient assertion of ITC resorts.

4. Employees are not relaxed with the art work place.

5. Personnel are sad with the Pantry \& conference facilities supplied to them.

6. Employees enjoy that they will be not capable of balance their personal and expert life.

\section{CONCLUSIONS}

After the a success final touch of the survey i.e. on the same time as all employees submitted their comments we analyzed it in following procedures Consolidated file of all of the employees taken and problems faced through way of them had been considered. Then institution smart approximately the belief and troubles faced in organizations have been analyzed. Then reviews had been divided in step with gender and analyzed and ultimately reviews regular with seniority had been prepared from which the consolidated record that have been enclosed indicates the overall stages of worker pleasure at ITC hotels.After studying the consolidated report, I idea the underneath hints given through me might in all likelihood assist ITC inns to create an amicable \& peaceful surroundings wherein people experience proud to work. [26],[28],[30]

The pointers are follows:

1. A number of the questions for which bad comments became expected had been deleted, for my part once they have been making plans to take an common opinion approximately employee satisfaction levels all of the elements related to employee satisfaction need to be blanketed. [31],[33],[35]

2. Brief and activate movement have to be taken for the areas placed in employee remarks which want improvement.

3. Employee have to take delivery of greater time to replenish the survey. four. Present day schooling and improvement periods had been useful to employees. Maximum of them felt that the schooling intervals want to keep and this consultation

ought to recognition more on their technical and mild abilties. [32]five. regardless of company providing many blessings to employees, most of them aren't glad with benefits plans of the company company, I would really like to advocate ITC accommodations to transport for advantages like sodex-ho passes, partner coverage and so forth..

\section{REFERENCES}

1. G BharthVajan R., Ramachandran S.,Psychographic dimensions of training,2016,International Journal of Pharmacy and Technology,V-8,I-4,P-23727-23729

2. Balakrishnan P., Bharthvajan R.,A study on human resource planning in hospitals in Chennai City,2014,International Journal of Applied Engineering Research,V-9,I-22,P-7503-7507
3. Priyadarsini P., Bharthvajan R.,Role of emotional intelligence training programme in reducing the stress of the nurses,2014,International Journal of Applied Engineering Research,V-9,I-22,P-7411-7421

4. Kerinab Beenu G., Bharthvajan R.,Empirical analysis on the cosmetic buying behavior of young women in South India,2014,International Journal of Applied Engineering Research,V-9,I-22,P-7361-7366

5. Balakrishnan P., Bharthvajan R.,Whistling in the wind,2014,International Journal of Applied Engineering Research,V-9,I-22,P-7586-7593

6. Krishnan B., Peter M.,Health hazards of Indian Bpo employee-an alarming issue,2014,International Journal of Applied Engineering Research,V-9,I-22,P-7336-7341

7. Kerinab Beenu G.H., Peter M.,Role of insurance in economic development,2014,International Journal of Applied Engineering Research,V-9,I-22,P-7532-7539

8. Balakrishnan P., Peter M., Priyadarsini P.,Efficiency of safety measures for wellbeing of employees in manufacturing industry,2014,International Journal of Applied Engineering Research,V-9,I-22,P-7376-7382

9. Anbarasi M., Praveen Kumar S.,Online sales promotions of herbal products and its effectiveness towards tanisha.com,2019,Indian Journal of Public Health Research and Development,V-10,I-1,P-195-200

10. Anbarasi M., Praveen Kumar S., Various online marketing and promotions strategies to improve the validation towards the organic products in the pharmaceutical sectors,2019,Indian Journal of Public Health Research and Development,V-10,I-1,P-263-269

11. Loganathan R., Praveen Kumar S.,Grievance handling a key factor for solving issues of employees in an organization,2014,International Journal of Applied Engineering Research,V-9,I-22,P-7483-7491

12. Loganathan R., Praveen Kumar S.,Study on preference of private label brands in super and Hypermarkets, 2014,International Journal of Applied Engineering Research,V-9,I-22,P-7327-7335

13. Smitha M., Praveen Kumar S.,Understanding stress and its managementamong the nurses in Chennai city,2014,International Journal of Applied Engineering Research,V-9,I-22,P-7560-7565

14. Kerinab Beenu G.H., Praveen Kumar S.,A study on the investment behavior of Chennai investors in mutual fund schemes,2014,International Journal of Applied Engineering Research,V-9,I-22,P-7520-7525

15. Loganathan R., Praveen Kumar S.,Retention strategies key for organizational productivity,2014,International Journal of Applied Engineering Research,V-9,I-22,P-7443-7447

16. Pavithra J., Ganesan M., Brindha G.,State wise analysis of microfinance sector in India,2016,International Journal of Pharmacy and Technology,V-8,I-4,P-23417-23432

17. Pavithra J., Ganesan M.,A comparative study on microfinance in India and abroad,2016,International Journal of Applied Business and Economic Research,V-14,I-8,P-5471-5476

18. Pavithra J., Ganesan M.,A study on awareness and impact of micro-financial schemes, 2016,International Journal of Applied Business and Economic Research,V-14,I-8,P-5449-5460

19. Senthilmurugan P., Pavithra J.,Consumer preference towards organised retailing with reference to Big Bazaar,2014,International Journal of Applied Engineering Research,V-9,I-22,P-7469-7475

20. Senthilmurugan P., Pavithra J.,Implication of social media marketing in growing healthcare industry,2014,International Journal of Applied Engineering Research,V-9,I-22,P-7448-7456

21. Loganathan R., Pavithra J.,Consumer perception towards private label brand over other brands in super markets and hypermarkets,2014,International Journal of Applied Engineering Research,V-9,I-22,P-7355-7360

22. Kerinab Beenu G., Pavithra J.,Tradeâ€"off between liquidity and profitability in logistics industry,2014,International Journal of Applied Engineering Research,V-9,I-22,P-7398-7401

23. Kerinab Beenu G., Pavithra J.,A study on the prospective consumerâ€(M perception towards utility cars in Chennai city,2014,International Journal of Applied Engineering Research,V-9,I-22,P-7526-7531

24. Pavithra J., Dilli Babu P., Ambuli T.V.,A study on budgetary control at Maruti Service Masters, Chennai,2014,International Journal of Applied Business and Economic Research,V-12,I-2,P-151-161

25. Pavithra J., Dilli Babu P., Ambuli T.V.,A study on customer satisfaction of retro Garments Pvt Ltd, Chennai,2014,International Journal of Applied Business and Economic Research,V-12,I-2,P-381-391

26. Kerinab Beenu G.H., Pavithra J., Senthilmurugan P.,A study on the influence of promotional activities for TATA ARIA among consumers in Chennai,2014,International Journal of Applied Engineering Research,V-9,I-22,P-7572-7578

27. Vijayaragavan S.P.,An investigative expert that's general FBG sensors,International Journal of Mechanical Engineering and

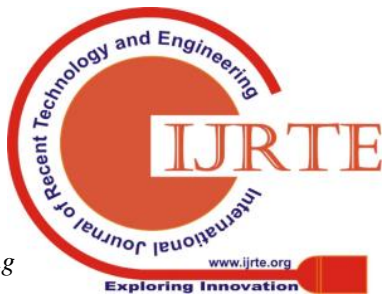


Technology,V-8,I-8,PP-1500-1505,Y-2017

28. Vijayaragavan S.P.,Equalization routing protocol for Wi-Fi sensor strategy,International Journal of Mechanical Engineering and Technology,V-8,I-8,PP-1662-1666,Y-2017

29. Karthik B., Kiran Kumar T.V.U., Vijayaragavan P., Bharath Kumaran E.,Design of a digital PLL using 0.35 $\hat{\mathrm{I}}^{1 / 4 \mathrm{~m}}$ CMOS technology,Middle East Journal of Scientific Research,V-18,I-12,PP-1803-1806,Y-2013

30. Kanniga E., Selvaramarathnam K., Sundararajan M.,Kandigital bike operating system,Middle - East Journal of Scientific Research,V

31. Jasmin M., Vigneshwaran T., Beulah Hemalatha S.,Design of power aware on chip embedded memory based FSM encoding in FPGA,International Journal of Applied Engineering Research,V-10,I-2,PP-4487-4496,Y-2015

32. Jasmin M.,Optimization techniques for low power VLSI circuits,Middle East Journal of Scientific Research,V-20,I-9,PP-1082-1087,Y-2014

33. Jasmin M., Vigneswaran T.,Fuzzy controller for error control of on - Chip communication,2017 International Conference on Algorithms, Methodology, Models and Applications in Emerging Technologies, ICAMMAET 2017,V-2017-January,I-,PP-1-5,Y-2017

\section{AUTHORS PROFILE}

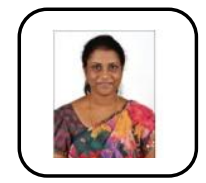

Magdalene Peter,Assistant Professor ,Department of MBA, Bharath Institute of Higher Education and Research, Tamilnadu, India

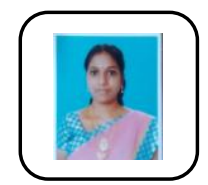

Dr.S.Fabiyola Kavitha, Associate Professor Department of MBA, Bharath Institute of Higher Education and Research, Tamilnadu, India

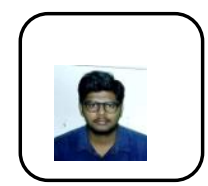

Kieerti Reddy ,Student, Department of MBA, Bharath Institute of Higher Education and Research, Tamilnadu, India 